\title{
ENTRE O AGRADÁVEL E O PSEUDOESTÉTICO: UMA DIALÉTICA PRÓPRIA DO CAMPO DA ARTE
}

BETWEEN THE PLEASANT AND THE PSEUDO-AESTHETIC: A DIALECTIC PROPER TO THE FIELD OF ART

ENTRE LO AGRADABLE Y EL PSEUDOESTÉTICO: UNA DIALÉCTICA PROPIA DEL CAMPO DEL ARTE

JOSÉ DERIBALDO GOMES DOS SANTOS. 


\section{RESUMO}

O artigo, de caráter teórico-bibliográfico, debate com Lukács o subitem Ciclo problemático do agradável, contido no capítulo 14 de sua Grande estética. A comunicação objetiva aclarar a relação entre o estético e o agradável, o que possibilita problematizar o conceito de pseudoestético. Essa problemática é imprescindível para o debate sobre a arte, dado que ilumina as criações humanas que, mesmo sem atingir a reflexão artística, cumprem uma missão importante para a vida cotidiana. Para atingir o objetivo, a comunicação se apoia numa leitura imanente do autor, destacando a relação entre o Antes e o Depois do efeito catártico. Sobre o desenvolvimento dessa tematização, a exposição aponta para a importância do efeito agradável para a vida cotidiana e, em consequência disso, para a produção e a recepção artísticas, indicando, entretanto, as distinções e as aproximações entre o estético e o agradável.

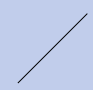

ABSTRACT

This theoretical bibliographical paper discusses, with Lukács, the Problematic Cycle of the pleasant (Chapter 14), which is part of his Great Aesthetics. The text aims at clarifying the relationship between the aesthetic and the pleasant, which makes it possible to debate the pseudo-aesthetic concept. This issue is essential when debating on art, since it sets light into human creations that, even though not achieving artistic reflection, fulfill an important mission for everyday life. In order to reach our goal, we read the author highlighting the connections between the Before and the After regarding the cathartic effect. On the development of this theme, the exhibition remakes the importance of the pleasant effect for daily life and, consequently, for artistic production and reception; indicating, however, the distinctions and approaches between the aesthetic and the pleasant.

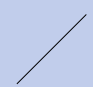

\section{RESUMEN}

El artículo, de carácter teórico bibliográfico, debate con Lukács lo subite Ciclo problemático del agradable, contenido en el capítulo 14 de su Gran estética. La comunicación objetiva aclarar la relación entre lo estético y lo agradable, lo que posibilita problematizar el concepto de pseudoestético. Esta problemática es imprescindible para el debate sobre el arte, dado que ilumina las creaciones humanas que incluso sin alcanzar la reflexión artística, cumplen una misión importante para la vida cotidiana. Para alcanzar el objetivo, la comunicación se apoya en una lectura inmanente del autor, destacando la relación entre el Antes y el Después del efecto catártico. Sobre el desarrollo de esta tematización, la exposición apunta a la importancia del efecto agradable para la vida cotidiana y, en consecuencia, para la producción y recepción artística; indicando, sin embargo, las distinciones y acercamientos entre lo estético y lo agradable.

\section{Palavras-chave:} pseudoestético; efeito agradável; efeito catártico; produção e recepção artística; singularidade privada.

\section{KEYWORDS:} pseudo-aesthetic; pleasant effect; catechism effect; production and artistic reception; private singularity.

\section{Palabras clave:} pseudoestético; efecto agradable; efecto catártico; producción y recepción artística; singularidad privada. 


\section{INTRODUÇÃO}

\section{A INTENÇÃO DESTE ARTIGO é problematizar o conceito} de pseudoestético, chave para a compreensão da monumental obra do esteta húngaro. $\mathrm{O}$ debate posiciona-se dentro da problemática do que o autor denomina de Ciclo problemático do agradável. Para atingir o objetivo, destacar-se-á a relação entre o Antes e o Depois do efeito catártico, o que possibilitará o adequado entendimento da importância do efeito agradável para a vida cotidiana e, em consequência disso, para a produção e a recepção artísticas.

Para que se possa iniciar o debate, importa sumariar a relação existente entre as categorias Antes e Depois do efeito estético e a articulação que elas têm com o par categorial homem-inteiro/homem-inteiramente.

As categorias do Antes e do Depois do efeito estético permitem a transição entre a vida e a arte, e desta para aquela, uma vez que dirigem a regulação dos efeitos da vida sobre a arte, bem como orientam os efeitos retroativos da obra acabada 
sobre a vida cotidiana. O Antes é composto pela história de cada ser humano até que ele se depare com a obra que lhe causa comoção catártica. Esse estado comotivo, por sua força depuradora, põe o passado do sujeito humano (o Antes) em profunda reflexão. Já o Depois consiste exatamente no modo como esse sujeito receptor, ainda como homem-inteiro, livra-se de suas sugestões, e já como homem-inteiramente, elabora o adquirido, transformando-o em algo decididamente novo para sua vida desse instante em diante.

A relação entre homem-inteiro, experimentada no cotidiano, e homem-inteiramente, acometido pelo efeito causado pela obra de arte, se dá de modo recíproco. A arte é o veículo que condensa e abriga a transição de um momento a outro, isto é, o tráfego da condição de homem-inteiro à condição de homem-inteiramente. Em síntese, é o momento em que o ser social, imerso em sua vida cotidiana (homem-inteiro), acessa, ainda que momentaneamente, um mundo qualitativamente distinto do da cotidianidade, um mundo apropriado ao humano. Numa expressão: um mundo em que o sujeito humano possa se sentir homem-inteiramente.

Lukács utiliza a categoria homem-inteiro (der ganze Mensch) para designar, portanto, o sujeito humano que vive no cotidiano. Do modo como compreende o autor, para tornar-se homem-inteiramente (der Mensch ganz), este sujeito precisa libertar-se do meramente imediato para assim acessar, ainda que por alguns instantes, por meio do efeito da obra de arte, a plenitude do humano.

Como explica Tertulian (2008, p. 276, grifo do autor):

O destaque necessariamente unilateral da experiência estética através de um sentido ou um ‘órgão’ determinado de recepção do mundo, levando à homogeneização correspondente da matéria da obra, é descrito como um processo de condensação e expressão da personalidade integral. Lukács caracteriza este duplo processo de eclosão da imanência sensível e da elaboração em seu interior de um mundo sui generis como a necessária passagem da experiência heteróclita e disparatada do ho- 
plenitude, com todas suas pulsões e faculdades mobilizadas e condensadas, da subjetividade estética (o que denomina der Mensch ganz).

Esclarecidos esses pontos necessários, opta-se por iniciar a tematização considerando que pseudoestéticas são as formações e reações emotivas que, mesmo não possuindo em seu modo de aparição imediata e em suas determinações decisivas os elementos artísticos, aproximam-se ao estético.

Essa problemática é imprescindível para o debate sobre a arte, uma vez que existem muitas criações humanas cuja aparição e contemplação provocam sua atribuição a qualidade de obra de arte. Quando tais criações são miradas sob a análise estética, padecem de valor artístico, no entanto, cumprem a missão para um determinado indivíduo e até para grupos de sujeitos.

Como nos demais problemas estéticos enfrentados pelo esteta húngaro, aqui também será o cotidiano o elemento balizador para se tematizar o problema do agradável, dado que as verdadeiras e autênticas relações entre a cotidianidade e a arte exprimem problemas reais. As recém-estudadas categorias nodais, principalmente a antropomorfização e a desantropomorfização, servirão de elo ao desenvolvimento da discussão, pois elas possibilitam que se configure o caráter específico das formas de reflexos que nascem do cotidiano e se alçam ao patamar de objetivações superiores, a exemplo da arte e da ciência, entre outras esferas.

\section{ENTRE O AGRADÁVEL E O ÚTIL: EM BUSCA DA BASE DO ESTÉTICO}

O centro da problemática continua sendo, por uma parte, as interpretações mecanicistas e, por outra, as concepções idealistas. Enquanto o materialismo positivista e mecânico entende que o campo estético se dissolve completamente na vida cotidiana, o idealismo enxerga a beleza como a realização 
suprema da arte. Naquele, a arte é somente um fenômeno social; neste, o belo e o artístico se separam sem que haja qualquer transição em relação ao cotidiano. Se o caráter ambíguo e vago do conceito de beleza impede o adequado tratamento da questão, o mecanismo que liga, diretamente e sem mediações, a arte à vida cotidiana obstrui o devido entendimento da temática. O problema, para ser devidamente compreendido, precisa ser posto de modo que se entendam suas reais contradições.

Para tratar a questão do agradável na arte, conforme (LUKÁCS, 1967b), é necessário delimitar a problemática de acordo com sua estrutura real e concretamente existente na vida cotidiana. Apenas assim é possível captar as determinações que, mesmo aparentemente pertencendo ao estético, em essência, são esteticamente discrepantes. Com isso claro, é necessário demonstrar como essas determinações, que são próprias da vida concreta, produzem diferentes elementos que, mesmo independentes da arte, nascem da vida.

Oportuno exemplificar, para que fique evidente como as análises estéticas geralmente caem em equívocos, qual a proposta que o idealismo apresenta como modelo para se compreender a relação que a arte mantém com o plano da totalidade. Como anota o húngaro, verificam-se exageros idealistas desde seu fundamento na Antiguidade clássica com Platão, passando por Escoto Eriúgena até chegar a Kant. A originalidade da proposta kantiana, cuja base nutre o idealismo contemporâneo, como escreve Lukács (1967b, p. 210), consiste exclusivamente em fazer da estética “[...] um âmbito intermédio que, graças ao desinteresse que domina nele, se diferencia para ‘baixo’ do agradável e, para ‘cima’, da moral, pois o agradável e a moral encontram-se ambos sob o império do interesse".

Para o húngaro, a estética, considerada no plano ontológico, processa-se na constante transição entre a prática e a suspensão de suas finalidades imediatas. Precisamente na indestrutível articulação unitária entre a posição de fim e o exame "desinteressado" do produto planejado, reside a "harmonia contraditória" que peculiariza o processo de criação artística.

A tese do marxista húngaro é que, no processo criador, cujo resultado é uma autêntica conformação artística, nunca há a produção de uma supressão; produz-se, com efeito, uma suspensão, embora que transitória. É preciso reconhecer, 
contudo, que o caráter imediato da receptividade pura certifica, aparentemente, a tese do desinteresse de Kant, uma vez que, no momento da entrega imediata à obra em sua completa autenticidade, o receptor se desliga completamente dos interesses imediatos do cotidiano. Ao se observar com atenção esse fenômeno, indo além dos elementos aparentes, verifica-se que esse desligamento não se processa como uma supressão do interesse vivente do receptor; ele é tão somente uma suspensão transitória.

Não há como negar, dado que isso anularia o campo de contato entre arte e vida, que a área em que se processa a receptividade estética está impregnada do interesse mundanamente humano. Esse é o principal motivo pelo qual se deve abandonar o simplismo com que o idealismo aborda a problemática do agradável na arte, seja essa simplificação antiga, medieval, moderna ou contemporânea.

Para expor a problemática aqui enfrentada de modo convincente, torna-se necessário esclarecer que a efetiva cisão entre o estético e o agradável relaciona-se, diretamente, com a superação ou com a preservação da singularidade privada dada na imediaticidade. Quando a singularidade privada é preservada em sua imediatez, o agradável tem acento primordial. O estético apenas ocorre quando a particularidade, por seu movimento purificador, consegue superar e, ao mesmo tempo, preservar a singularidade privada em sua imediaticidade. Essa purificação é o elemento que confere ao campo artístico sua marca patente.

A metodologia para analisar o problema agora plantado, portanto, não pode abandonar a existência do seguinte círculo dialético: nasce na vida para chegar ao estético e deste, quando atinge o âmago autêntico do drama humano, retorna à cotidianidade. Para explicar o método referente à estética, (LUKÁCS, 1967b) insiste que é preciso relacionar os problemas humanos, a totalidade dinâmica da vida, com o resultado expresso nas obras de arte. Isso se consegue, segundo o autor, quando se opera o que (MARX, 2008) chamou de abstrações razoáveis; isto é, “[...] mediante uma abstração plenamente justificada desde o ponto de vista de uma metodologia da estética, a relação humana com as obras de arte da totalidade dinâmica da vida”. (LUKÁCS, 1967b, p. 217) 
Os pressupostos de partida para entender adequadamente os problemas agora debatidos precisam considerar a especificidade da dialética estética, que retira o material vital fornecido pela vida para alimentar a conformação artística e, dessa refiguração, quando o elemento refigurado atinge autenticamente a problemática dos viventes em forma de arte, retorna ao cotidiano para enriquecê-lo. Sobre a base desses pressupostos, interessa a Lukács saber como o estético conecta-se, por uma parte, com o agradável e, por outra, distingue-se dele. É preciso ponderar, assim, que a questão da agradabilidade é apenas uma parte - embora muito importante - da esfera estética.

À medida que o sujeito humano afirma a si próprio, na relação direta ou indireta de objetos ou grupos de objetos com sua própria pessoa, cria-se, por meio da realização útil de sua produção, a emoção do que é ou não agradável. Para o caso do desenvolvimento da estética, o elo de disputa para a devida formulação da problemática é a aproximação e o distanciamento entre o útil e o agradável. Tudo que se considera agradável a uma pessoa, o é como categoria subjetiva; já a utilidade, por sua necessidade de dar resultado ao desenvolvimento social, é uma categoria objetiva. Nesta última predomina o caráter desantropomórfico; já no agradável a predominância é antropomórfica.

Duas advertências, contudo, devem estar claras: primeiro, existem muitas transições e diversos pontos de contato entre a utilidade e a agradabilidade; segundo, o desejo humano de unir o agradável com o útil pode levar, em muitos casos, ao fracasso da finalidade planejada. Por regra geral, é um equívoco considerar diretamente o caminho que leva do agradável ao útil: "o homem da cotidianidade não pode, muitas vezes, realizar o útil mais que eliminando na preparação de seu plano de ação todos os momentos subjetivos e todas as possibilidades dessa ordem, dirigindo a atenção exclusivamente à objetividade da situação, dos meios etc.". (LUKÁCS, 1967b, p. 220)

O processo inverso é o que importa para se entender a relação entre o agradável e o útil, pois, na maioria das ações em que se obtém êxito na prática cotidiana, o útil abre a possibilidade de se desdobrar no agradável. Os exemplos são muitos e de diversas ordens; pensemos no ritmo do trabalho, que resulta na satisfação agradável obtida por meio do melhor desempenho do próprio ato de trabalho e na ornamentação de determinada ferramenta que possibilita ao trabalhador um 
aumento em sua produção diária. Pode-se mencionar também a colaboração entre o cão e o caçador, em que este sente relativa satisfação ao se comunicar com o animal, ou ainda o resultado que se consegue com o cozimento de alimentos para o consumo humano, que se processa com prazer e satisfação degustativa enquanto alimenta o próprio corpo.

Essa síntese permite inferir que tanto o agradável como o estético se desenvolvem a partir de reflexos antropomorfizados. Essa classe de reflexo nasce da experiência do sujeito humano com os objetos dados que, por sua vez, estão articulados com a sucessão de acontecimentos da vida cotidiana. A relação da experiência do vivente, associada aos acontecimentos cotidianos, possibilita ao sujeito refletir tais acontecimentos tomando a si como referência: antropomorficamente. Isso comprova uma fronteira frutífera entre o campo estético e a esfera do agradável. No entanto, mesmo que a agradabilidade se converta em elemento da estética, não se pode afirmar que o agradável é o objeto central do campo estético. Os elementos agradáveis, com efeito, apenas alimentam, como muitos outros fenômenos da vida, a vivência cotidiana; por isso, desembocam no estético.

Pontuar esse limite é importante, uma vez que considerar o agradável como objeto da estética é falsificar a adequada compreensão da temática. Apenas o conhecimento de como o agradável se forma, em seu modo puro e originário ser-em-si de manifestação, pode clarear a devida delimitação dessa fronteira sem macular as determinações, suas muitas e fluidas transições, que aproximam e distanciam a agradabilidade do estético.

Com esses elementos postos de modo límpido e em plano ontológico, podem-se formular adequadamente os dois princípios pelos quais se deve enfrentar o problema do agradável. Em primeiro termo, é preciso considerar que o agradável tem caráter geral e aparentemente quase ilimitado. Em segundo lugar, ao tempo que possui caráter quase ilimitado, a esfera do agradável é o campo da vida que mais conhece o acidente. A problemática fica mais evidente se se considera que os efeitos agradáveis ao sujeito humano, por um lado, podem desencadear uma enorme quantidade de estímulos internos e externos que, de acordo com cada sujeito vivente, podem ser interessantes para uns e repulsivos para outros; por outro lado, é preciso problematizar os acasos presentes nessa questão. 
Essa análise, contudo, deve ser efetuada com prudência, dado que em toda casualidade repousa uma condicionante causal. É preciso observar que, em determinados viventes, a utilidade apenas chega ao êxito quando há a completa superação dos elementos agradáveis. Não se pode esquecer, para esses casos, a influência que a moda tem sobre o sujeito humano. Outra situação que deve estar clara é o fato de que um determinado indivíduo em uma dada situação pode considerar algo agradável e, posteriormente, em outras circunstâncias, sem maiores conflitos, abandonar completamente o que anteriormente considerou como coisa agradável.

Mesmo que o vivente abandone sua posição posteriormente, o agradável tem caráter definitivo, pois a sensação que o fez considerar aquela situação como agradável está relacionada à dependência daquele momento que causou a sensação. Isso atenua o constrangimento de ter de admitir, posteriormente, aquilo como desagradável. O caráter que emana do objeto que causou, no passado, a emoção agradável faz com que toda experiência desse porte seja insuperável em sua momentaneidade: “[...] neste caso segue sendo o hic et nunc mais imediato de cada homem à instância última, e definitivamente decisiva em cada instante, do que vai se sentir como agradável”. (LUKÁCS, 1967b, p. 224) Mais uma vez, não se pode esconder que a moda, as convenções, entre outros elementos, impõem ao sujeito humano decisões contrárias às suas intenções.

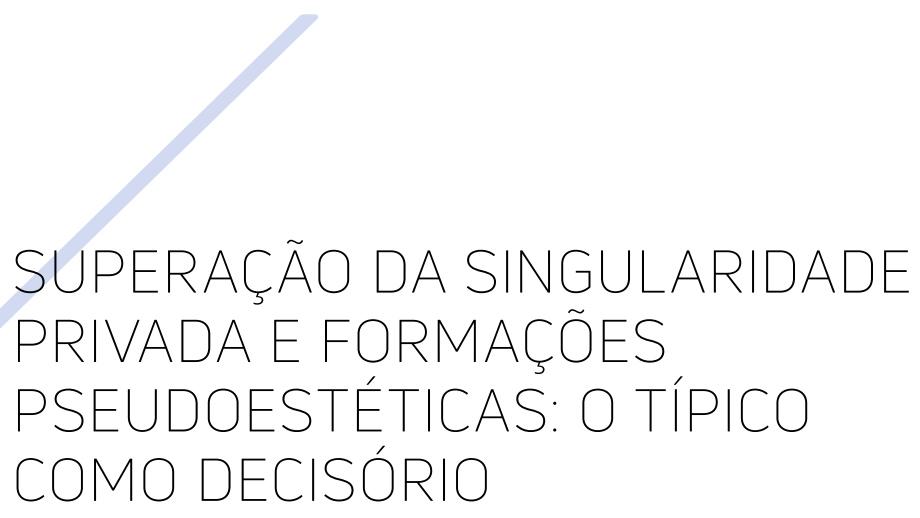

Para completar a estrutura social do agradável, precisamos virar o foco para o seu momento objetivo. A objetividade concretamente social empurra o sujeito humano para aderir ao que determinada cultura de dado período - de uma classe, de uma nação etc. - entende como agradável. ${ }^{1}$ Precisamente
1 A música Corta-jaca é uma das composições mais conhecidas de Chiquinha Gonzaga. Um fato, entre muitos que registram a trajetória dessa composição, que nascera com o título 0 gaúcho, merece ser destacado como elemento problematizador do que cada período social entende como agradável, embora o exemplo ilustrado seja restrito ao campo musical, ele expressa como a elite de cada momento constitui sua moda. Ainda que o caso da música em questão seja utilizado pelo senador Rui Barbosa para demonstrar sua ira por ter sido derrotado eleitoralmente por Hermes da Fonseca, ele serve como modelo para ilustrar como a moda influencia o gosto de ocasião, orientando o que é ou não agradável. Como escreve, sobre a polêmica, (NASCIMENTO, 2017, p. 41): "[...] de forma mais cáustica e severa, da boca do senador Rui Barbosa, que, num discurso em sessão do Senado Federal, ridicularizou a música e a festividade ao redor dela". Segue o discurso do senador transcrito por Nascimento (2017, p. 41): “Uma das folhas de ontem estampou em fac-símile o programa da recepção presidencial em que, diante do corpo diplomático, da mais fina sociedade do Rio de Janeiro, aqueles que deviam dar ao país o exemplo das maneiras mais distintas e dos costumes mais reservados elevaram o corta-jaca à altura de uma instituição social. Mas o corta-jaca de que eu ouvira falar há muito tempo, que vem a ser ele, Sr. Presidente? A mais baixa, a mais chula, 
aqui há uma boa oportunidade para distinguir com bastante clareza o estético do agradável - nossa intenção, a partir de agora.

Como anota nosso autor, a característica comum a toda grande obra de arte reside no fato de ela cobrar do receptor que ele ultrapasse sua íntima esfera privada. Se a experiência receptiva do agradável se converte em elemento da vida cotidiana em que se preservam os dados privados de cada sujeito vivente; se a determinação histórico-social não abandona o caráter da personalidade singular sem que ela possa se modificar em essência, não há a produção do fator estético. O estético, portanto, precisa ultrapassar o meramente privado, dado elementar de toda conformação estética.

Claro, não há dúvida de que o sujeito humano é uma pessoa singular e privada. A vida humana, não obstante, concentra a contraditória unidade composta pela seguinte dupla determinação: ao tempo que a pessoa humana é singular e privada, a vida social, no entanto, move constantemente o vivente para que ele, não sem contradições, ultrapasse a mera singularidade privada. Os atos mais elementares da vida social demonstram constantemente que essa dupla determinação não pode ser eliminada da vida humana. Basta lembrar que todo ato de trabalho, mesmo o mais primitivo, guarda generalizações que alçam o trabalhador para além da imediatez de sua vida privada. Lembre-se, como ilustração, da incorporação da ferramenta ao processo laboral, em que a subjetividade do trabalhador se levanta até uma generalização; quanto mais desenvolvido for o processo de trabalho, mais generalizado se torna o levantar dessa subjetividade.

O que mais importa retirar dessa dialética é que a personalidade privada dos homens e mulheres é derivada das condições materiais da existência social; o sujeito, ao interferir nas condições da existência social, modifica sua própria existência. Nesse processo dinâmico e nunca mecânico, a ação da particularidade, motivada pelas forças humanas de cada indivíduo dado, age no sentido de superar sua singularidade privada. Como é natural, as transformações reais são, frequentemente, como ocorre nas decisões morais ou com a catarse estética, muito violentas. Para Lukács (1967b, p. 229), mesmo que tais casos possam soerguer uma pessoa para um estado qualitativamente novo de vivência, não “[...] se suprime ou se destrói a peculiar vinculação contraditória da particularidade com sua superação". 
Para que não paire confusões, é importante aclarar que quando se fala em privado e singular, a referência deve cair sobre a natureza inata de cada homem e de cada mulher. Isto é, suas peculiaridades fisiológico-psicológicas construídas desde o nascimento, o que inclui, naturalmente, as interferências educacionais (escolares e extraescolares). ${ }^{2}$

Como já sabemos que o agradável se desprende do útil e não o contrário, o que nos interessa neste momento é a distinção entre o agradável e o estético. Nosso problema reside no fato de que, enquanto o útil tem caráter desantropomórfico, o agradável e o estético possuem naturezas antropomórficas. Por isso, a exposição explora a categoria da particularidade no intuito de definir a diferença entre o que é estético e o que é apenas agradável, já que a estética, por meio da particularidade, supera a mera singularidade privada. Temos como objetivo demonstrar que o agradável não proporciona essa superação. Como a categoria da particularidade relaciona-se intrinsecamente com o típico, há a necessidade, para avançar sobre a nossa problemática, de analisar a categoria da tipicidade. O mote para agregar o típico ao atual estado da discussão é a relação entre vida cotidiana e arte.

Toda obra de autenticidade artística carrega, espontaneamente, no seu âmago, a vida cotidiana, estando, ao mesmo tempo, separada dela. Perante tal complexidade, somente a análise do típico permite avançar sobre a peculiaridade da superação dessa contradição, uma vez que toda tipicidade encoraja tal paradoxo; isto é, o típico apenas pode existir se permitir que a obra dê luz a essa antinomia: sujeito privado por um lado e generalidade por outro. Toda intenção de tipicidade, com efeito, funda-se na singularidade privada, levantando determinados momentos dela à altura do típico. Caso não processe esse movimento de soerguimento, como explica Lukács (1967b, p. 238), “[...] será uma mera abstração do humano que hesitará entre o inteligível e o experienciável, e será fortemente impreciso para o primeiro e fortemente indeterminado para o segundo".

Quando o artista, por mais esforçado, sincero, bem-intencionado e moralmente avançado que seja, não consegue libertar a singularidade privada, sua obra, mesmo que atinja a perfeição técnico-artística, alcança liminarmente um mero naturalismo. A particularidade como categoria central da estética, que, por sua monta, tem modo de manifestação sensível por meio do típico, inclina sua estrutura 
depuradora para a unificação da contradição aqui tratada: a contraditoriedade entre singular e universal.

O filósofo magiar explica como a singularidade, mesmo depois de superada, preserva determinado caráter terreno, mundano. Para o húngaro, o movimento depurador da particularidade é o responsável por fazer com que o singular, superado esteticamente, faça aparecer, precisamente por força da ação do típico, o singular-privado. Essa superação, também por meio da particularidade, produz a unidade com o humano, “[...] na qual a singularidade privada se une inseparavelmente com esse elemento humano específico, e a tensão polar [a contraditoriedade entre singular e universal] se converte em princípio vivificador do típico". (LUKÁCS, 1967b, p. 238)

Importante repetir, pois não se podem esquecer os pressupostos estéticos lukacsianos, que essa referência à vivência terrena do sujeito, conseguida mesmo depois da superação, é um elemento básico da vida cotidiana dos viventes. Os sujeitos humanos, em suas vidas cotidianas, já promovem determinado enriquecimento da imagem que colhem das situações dadas. O que a obra desperta e faz surgir em cada receptor determinado é o que chamamos acima de caráter terreno, mundano, ou seja, “inverossimilitude milagrosa”: caráter “[...] antropomorfizador, orientado à imanência do centro humano". (LUKÁCS, 1967b, p. 241)

O humano específico nasce mesmo dos diferentes sujeitos singulares em suas vivências diárias. O específico do humano, o que é propriedade do gênero, não pode ser entendido em contraposição excludente à singularidade privada. Não se pode, metafisicamente, fixar a separação entre o singular privado e o específico. O sujeito humano é um resultado que, por intermédio de suas atividades, modifica-se continuamente. Ele não pode ser o resultado de uma substância fixa eternamente - universalidade -, tampouco um nível imóvel que possua uma existência própria completamente independente dos demais indivíduos e apartado metafisicamente de suas atividades - singularidade.

A obra de arte possibilita um elo onde se resolve a contradição, pois ela possui, como destacado, um duplo caráter: se, por um lado, carrega uma objetividade 
que anda com os pés no chão social dos viventes - é pedestre ${ }^{3}$-, por outro, não pode ser encarada como se fosse a realidade concretamente dada, ou seja, revela determinado milagre mundano.

Na explicação de Lukács (1967b, p. 240-1):

A obra assim nascida concentra em forma todas essas aspirações, e por isso pode desencadear o efeito catártico pelo qual o singular e o privado, superado até fazer-se específico e convertido em centro das irradiações evocadoras, provoca no receptor a vivência que comove sua emotividade; uma realidade na qual este aspecto é a dominante ordenadora e que, entretanto, e por isso mesmo, éa única realidade adequada ao homem, é diversa, distinta, nova, mais individual e, ao mesmo tempo, mais abrangente, mais cheia de mundo.

O que a autêntica obra carrega é a mundanidade reveladora dos processos contraditórios que os diversos viventes experimentam na vida cotidiana. Tal revelação apenas é iluminada pela necessidade imposta pela vida de se refletir o mundanamente humano. Por ser contraditória, a profundidade desse processo, ao tempo que abarca cada sujeito humano revelando suas mais essenciais potências, também, a depender da personalidade privada de cada vivente, revela o constrangimento com suas atitudes e com as ações dos demais indivíduos. Disso se depreende o que mais importa para o atual estágio da nossa exposição: que a vivência do agradável, diferentemente da estética, proporciona a cada sujeito humano uma satisfação momentânea.

Em outras palavras, a mundanidade da autenticidade artística é o critério de distinção entre a estética e o agradável, pois enquanto este possibilita uma satisfação momentânea, aquela cria o espaço de jogo, ludicidade e tensão cujo objetivo é fazer com que o sujeito humano ultrapasse - conservando - dialeticamente sua singularidade privada.

Ainda que a maioria absoluta das criações que se consideram artísticas não tenha nascedouro nas mais profundas aspirações dos viventes, a chama que se transforma em arte tem de surgir das imediatas necessidades da vida concreta.
3 Na passagem a seguir, mesmo que Marx esteja se referindo ao processo de compra e venda da força de trabalho, suas reflexões servem para o debate sobre o sujeito humano que vive com os pés no chão e se defronta com elementos agradáveis e desagradáveis cotidianamente. 0 que nos interessa da citação do pensador alemão é a determinação do vivente que, para viver, precisa produzir sua própria existência; por isso o chamamos de sujeito pedestre. Como escreve Marx (1996, p. 285-286): "Ninguém, nem mesmo um músico do porvir, pode alimentar-se com produtos do futuro, portanto também não de valores de uso cuja produção não esteja concluída, e, como nos primeiros dias de sua aparição sobre o palco do mundo, o homem ainda precisa consumir a cada dia, antes de produzir e enquanto produz. Caso os produtos sejam produzidos como mercadorias, então precisam ser vendidos depois de produzidos, e só podem satisfazer às necessidades do produtor depois da venda". 
As poucas obras que, ao longo da história, conseguem revelar a inverossimilitude do específico humano provam que a razão da existência da arte é registrar as profundíssimas necessidades específicas da humanidade que, de maneira geral são obstaculizadas e/ou ocultadas. Essas grandes conquistas, naturalmente, apenas se efetivam por meio de grandes talentos.

Para que essa afirmação não caia na crença de que a arte é fruto exclusivamente da ação do gênio talentoso, é preciso considerar a seguinte advertência: embora não se possa dispensar a ação do talento genial, as aspirações e necessidades da vida têm um duplo caráter. Toda moção de cada indivíduo particular pertence à totalidade da espécie; não é, de modo algum, somente a soma das diversas atividades singulares. Quando o talento artístico elege um fenômeno ou um grupo de fenômenos para dar forma, escolhe espontaneamente perante suas próprias decisões; não obstante, o faz, como define (MARX, 2011), sob as condições herdadas histórico-socialmente.

A eleição do material vital a ser conformado pelo artista pode ser explicada por meio da comparação entre o reflexo científico e o artístico. No caso do primeiro, o critério deve ser uma aproximação o mais fiel possível ao objeto realmente concreto; o reflexo estético, por seu caráter antropomórfico, mesmo sem se desligar da realidade concreta, precisa alçar o singular privado, escolhido originalmente do cotidiano, ao patamar da especificidade humana. Esse alçar ao típico é possível pela ação do movimento causado pela particularidade que age no sentido da superação dialética do singular: “[...] o conteúdo da generalização estética consiste precisamente em captar a individualidade, o ser-assim dos objetos [...], mesmo que conserve e até intensifique o modo como os elementos se manifestam na aparência da obra". (LUKÁCS, 1967b, p. 249)

Para o esteta de Budapeste, como comprova a história da arte, não é por acaso que o aparecimento das grandes obras ocorra vinculado à missão social que elas cumprem em cada momento histórico. O exemplo de Shakespeare é bem representativo, uma vez que o poeta inglês se entregou à corps perdu ao material social que se dispunha à sua frente para criar seus dramas. Nesse artista, há uma profunda vinculação entre a obra e o cumprimento de sua missão social. Como sustenta Lukács, a motivação shakespeariana para criar, por exemplo, Hamlet, 
Lear, Macbeth, Desdêmona, Otelo, entre outros personagens típicos, não se desliga da estrutura social que produz pessoas como aquelas a que Shakespeare deu vida em sua época.

São os impulsos individuais, os estímulos e as inibições sociais que, atuando juntos, cobram da conformação uma tendência ao especificamente humano. Desse conteúdo, a marcha histórica seleciona o que expressa com mais profundidade, amplitude e completude a novidade latente que precisa manifestar-se: “Somente a partir do ponto de vista da relação entre o agradável e o autenticamente artístico temos de considerar esse processo que contém todas as tendências estéticas e pseudoestéticas". (LUKÁCS, 1967b, p. 251)

Não há como compreender a dialética existente entre o agradável e o estético, considerando suas aproximações e distinções, sem levar em conta as componentes sociais presentes na subjetividade privada e que, por sua dialética, impõem-se na gênese e nos efeitos do agradável. Duas questões precisam ser aclaradas para que tal dialética não pareça um paradoxo insolúvel. O primeiro aspecto refere-se ao salto qualitativo que separa o estético do agradável. Sem dúvida, é um fato empiricamente documentado “[...] que as formações pseudoestéticas penetram frequentemente na cotidianidade dos homens muito mais veemente e extensivamente que as obras de arte mais importantes". (LUKÁCS, 1967b, p. 253) Visto historicamente, o efeito pseudoestético causado pelo elemento agradável é, porém, efêmero. O que conforma de modo duradouro a autoconsciência da humanidade é, apesar de todas as contradições, o efeito causado pelas grandes e autênticas obras de arte.

Já o segundo aspecto relaciona-se ao seguinte fato: o modo de aparição do agradável na imediatez cotidiana não tem caráter inequívoco, tampouco se apresenta de maneira simples. Nessa imediaticidade, a aparência fenomênica da agradabilidade a faz coincidir com algumas exigências da vida. Essa aparência é, em muitos casos, uma adequação a casos objetivos que cobram um efeito agradável do sujeito vivente. Importa destacar que o útil e o agradável nutrem com o sujeito humano uma relação que Ihe possibilita relacionar-se com o mundo externo. Tal relação é o que mais contribui para que o vivente desperte, afirme e desdobre suas capacidades e tendências vitais. O agradável, não obstante, por sua essência 
subjetiva, é um reflexo privado do mundo externo. Isso tem como consequência que uma reação análoga ao mundo externo, precisamente pelo caráter de singularidade privada do agradável, pode ter, como resultado objetivo da reação, uma amplificação ou atenuação daquelas tendências e capacidades vitais.

O que é preciso destacar energicamente, para que não paire qualquer componente duvidoso, é que enquanto o estético não pode ser a realidade concreta, senão seu reflexo, o agradável será sempre subjetivo privado. Este não tem como sair da personalidade privada e se generalizar por meio da movimentação da particularidade. Já o reflexo estético se alimenta constantemente da concretude da realidade, mesmo não sendo ela.

Lukács (1967b, p. 260) explica que, por meio da interação dialética com o mundo real, há uma seleção de determinado aspecto da vida; dessa eleição vital a arte cria um mundo apropriado ao humano, que, por sua força refigurativa, “[...] possibilita a manifestação máxima e mais adequada das determinações decisivas, positivas e negativas, dessas interações, e lhes dá forma; produz-se a suprema forma objetivada da autoconsciência da espécie".

Exatamente sobre as contradições entre o agradável e o estético é que as produções pseudoestéticas crescem ao ponto de se confundirem com o autenticamente artístico. O capitalismo, ainda que não se excluam suas contradições inerentes, valoriza a elaboração de técnicas que possam dominar, por intermédio da produção em série do agradável, as formas mais adequadas à difusão em massa. Isso tem, conforme Lukács (1967b, p. 255), efeito sobre a produção artística de duas maneiras: "por uma parte, a força crescente e cada vez mais autônoma das meras letras (e seus análogos em todas as artes) tende a eliminar violentamente as fronteiras que definem o estético [...]", bem como procuram obscurecer a essência própria da arte. Já por outra parte, mesmo que imposta pelo movimento da realidade, “[...] a autodefesa da arte ante essas pressões tende a um esoterismo artisticamente insano, [e] a uma oclusão voluntária [...]”. (LUKÁCS, 1967b, p. 255)

Imbricada à relação estabelecida entre o estético e o agradável, encontra-se a problemática do diletantismo. Segundo nosso autor, não há como enfrentar a tematização do diletantismo sem se referir ao modo como os homens e mulheres 
vivem no cotidiano, solo, como já sabemos, que pode dar lugar à intensificação da receptividade estética. Para exemplificar como o diletante se relaciona com determinada arte em seu cotidiano, o húngaro usa o caso do diletantismo musical. Pare ele, quando um sujeito qualquer, imerso em suas atividades diárias, utiliza o exercício meramente reprodutivo da música, não há, na maioria dos casos, uma pretensão de autenticidade artística.

Porém, a interpretação e a execução do aficionado, ainda que a partir de um ponto de vista artístico sejam deficientes, vão formando uma sensibilidade, uma compreensão, uma receptividade para as obras de arte musical que não costumam ser alcançadas por recepção direta, por simples audição. Esta é, sem dúvida, a forma mais acurada de atividade diletante, e desemboca em um aprofundamento e em uma intensificação da compreensão receptora. Não é frequente que os diletantismos tenham em outras artes o mesmo resultado; é excepcional que o diletantismo literário desperte ou promova compreensão da arte literária. (LUKÁCS, 1967b, p. 255)

O agradável, como entende o húngaro, concebido em seu sentido mais amplo, é uma fixação da consciência humana a um nível radical e limite de acaso. Mesmo que sua forma de manifestação imediata se apresente como uma necessidade fisiológica, psicológica ou de natureza estritamente social, o caráter do agradável é um caso especial de casualidade. O devido tratamento dessa tematização precisa considerar, em primeiro termo, que a análise dos elementos estéticos não pode separar a forma do conteúdo. A forma artística se refere a um conteúdo específico, portanto, apenas é possível alcançar sua essencialidade com essa consideração em primeiro plano. Se se separa o conteúdo, prendendo-o à singularidade privada, a forma que reveste esse conteúdo - que precisa ser vital para a humanidade e, por isso, tem de apresentar caráter mundano - não conseguirá ultrapassar um complexo causal de objetos que se encontra numa relação contingencial com determinados estados psíquicos dos homens e mulheres.

A confusão dá-se por intermédio do paradoxo estabelecido nas formações pseudoestéticas que priorizam o elemento agradável. Essas formações põem em ação 
os meios de reflexos e de expressão do campo estético, sem, no entanto, retirar a personalidade singular de sua imediatez. Em alguns casos, visto que não há como considerar a problemática de modo metafisicamente fechado, tais formações até atingem alguma eficácia artística, não obstante, fixam o sujeito humano na imediatez da cotidianidade.

Não se deve descuidar do fato de que as formações artisticamente autênticas também promovem a imediatez da vida cotidiana; aqui, todavia, o que a arte procura é conformar uma segunda imediatez, aquela que se refere à autoconsciência especificamente humana, encontrada apenas nas obras que objetivam adequadamente o elã humano. Quando o fator agradável ganha a centralidade da evocação, a segunda imediatez coincide e é absorvida pela primeira. Com esse acontecimento, as forças da forma assaltam casualmente a conformação, abandonando a relação de especificidade entre forma e conteúdo, o que possibilita, no limite de cada caso dado, fixar as relações cotidianas dos homens e mulheres com maior precisão do que ocorre, geralmente, na vida concretamente real. Isto é, relevar a descrição em detrimento da narração, conseguindo, no máximo de suas possibilidades, destacar o naturalismo em abandono ao realismo.

\section{NOTAS CONCLUSIVAS}

Para finalizar, precisamos adiantar algumas palavras sobre o Antes e o Depois do efeito artístico em relação à comoção catártica. Para Lukács (1967b), a arte possibilita que o homem-inteiro da cotidianidade, por intermédio do meio homogêneo da arte de que se trate, receba determinada orientação que guia suas evocações, o que transforma o sujeito do cotidiano em homem-inteiramente tomado pelo efeito catártico da obra acessada.

Quando esse sujeito humano se desprende da catarse, pois ela é um efeito passageiro, seu Depois, do efeito estético, estará comprometido para sempre. O Antes, naturalmente, não há como ser alterado. Registra-se, para evitar mal-entendidos, 
que a relação entre homem-inteiro, vivenciada no cotidiano, e homem-inteiramente, soerguido às objetivações superiores, processa-se dialeticamente.

A arte, por meio da catarse, é o elo que condensa e abriga a transição entre os dois momentos. O tráfego entre o homem-inteiro imerso no cotidiano à condição de homem-inteiramente afetado pelo efeito artístico, quando termina, faz com que o vivente regresse ao seu cotidiano e à sua condição de homem-inteiro. Nessa condição, que é a normalidade do sujeito humano em sua cotidianidade, o vivente, após a sacudida dada pela comoção catártica, não será o mesmo; carregará, agora, o Depois do efeito catártico.

Embora não tenha como modificar o Antes, sua vida em diante terá de conviver com as contradições entre o Antes e o Depois. Adverte-se, com efeito, que à arte não cabe garantir que o Depois possibilite determinada harmonia entre os desejos do sujeito vivente e a realidade concreta. É missão do efeito artístico criar um âmbito de tensão, jogo e ludicidade onde o sujeito humano possa acessar a humanidade de que ele é partícipe.

Em resumo, o efeito causado pela arte é o elemento mediante o qual o ser social imerso em sua vida cotidiana (homem-inteiro) acessa, ainda que transitoriamente, um mundo qualitativamente distinto de seu cotidiano, um mundo apropriado à sua humanidade: um mundo em que o sujeito pode vivenciar a experiência de ser homem-inteiramente.

Para o debate do agradável, importa destacar que na relação entre o Antes e o Depois inexiste algum vestígio de rigidez metafísica: “Pois quando analisamos o Antes e o Depois do comportamento propriamente estético para com a arte, não surpreendemos nenhuma situação fixa, senão uma corrente que vai da vida ao comportamento estético, e deste à vida”. (LUKÁCS, 1967b, p. 217) A vida cotidiana, em sua totalidade intensivamente dinâmica, acrescenta o autor, é um território limite de onde se ergue o comportamento estético. A arte, saída portanto da vida, quando autêntica, retroage novamente sobre a vida: enriquecendo-a.

Apenas um âmbito emocional de grande amplitude, e que seja intimamente interligado à profundidade humana, possibilita que o agradável influencie a criação 
artística desde seu nascedouro, ou seja, que interfira no Antes estético. Somente essa relação entre o espaço das emoções e sua conexão com a profundidade do mundo humano deixa aberta a possibilidade para que o agradável - em forma e em conteúdo - siga penetrando na vida cotidiana. Isso torna possível que a agradabilidade, ao penetrar profundamente na vida cotidiana, se irradie pela receptividade artística. O Depois da recepção estética possibilitará ao sujeito vivente desempenhar, mesmo que sua consciência sobre isso seja turva e parcial, o papel decisório acerca do que ele sente como agradável, bem como o modo de conseguir tal feito.

Como a imagem refletida do mundo mantém-se ao nível mundano da cotidianidade, fica claro que não se pode analisar a relação entre o agradável e o estético em fronteiras rígidas, pois há uma fluida e fértil transição entre os dois campos. Quando, portanto, abandona-se a formalidade idealista, por uma parte, e o irracionalismo, por outra, e considera-se a materialidade histórica da vida em sua ontologia pedestre, clareia-se o modo adequado acerca da distinção entre o agradável e o estético. Apenas desse modo evidencia-se a importância dos efeitos agradáveis para a vida humana e, consequentemente, para a estética.

Segundo sustenta o autor magiar, não há como imaginar o surgimento da arte sem a participação de um elo agradável. Do mesmo modo, jamais teria surgido o fator artístico se a vida humana fosse resumida ao que é agradável de um lado e desagradável de outro. Esses elementos, mesmo sendo fundamentos vitais para a arte, correspondem a um campo bem mais amplo do que o que concerne à estética. Cumpre destacar que o estético, como forma determinada de superação da esfera do agradável, difere deste de modo qualitativo; isto é, as categorias decisivas do campo estético não podem, com risco de fracasso artístico, visibilizar em primeiro plano o agradável. A arte, portanto, mesmo não dispensando o agradável, não se resume a ele. 


\section{REFERÊNCIAS}

LUKÁCS, G. Estética: la peculiaridad de lo estético. Barcelona: Ediciones Grijalbo, 1966a. v. 1.

LUKÁCS, G. Estética: la peculiaridad de lo estético. Barcelona: Ediciones Grijalbo, 1966b. v. 2.

LUKÁCS, G. Estética: la peculiaridad de lo estético. Barcelona: Ediciones Grijalbo, 1967a. v. 3.

LUKÁCS, G. Estética: la peculiaridad de lo estético. Barcelona: Ediciones Grijalbo, 1967b. v. 4.

MARX, K. Contribuição à crítica da economia política. São Paulo: Expressão Popular, 2008.

MARX, K. O 18 brumário de Luís Bonaparte. São Paulo: Boitempo, 2011.

MARX, K. O capital: crítica à economia política. São Paulo: Abril Cultural, 1996. (Coleção Os

Economistas, v. 1.t.1).

NASCIMENTO, R. Catete em ré menor: tensões da música na primeira República. Revista do Instituto de Estudos Brasileiros, São Paulo, n. 67, p. 38-56, 2017.

NETO ACCIOLY. A natureza das coisas. In: NETO ACCIOLY. Lembrança de um beijo. Recife: [s. n.], 1993.

TERTULIAN, N. Georg Lukács: etapas de seu pensamento estético. São Paulo: Ed. UNESP, 2008.

Deribaldo Santos: é doutor em Educação Brasileira pela Universidade Federal do Ceará (UFC); Residência pósdoutoral em Estética, na Universidad Complutense de Madrid (UCM); Professor da Faculdade de Educação, Ciências e Letras do Sertão Central da Universidade Estadual do Ceará (FECLESC-UECE); Pesquisador produtividade nível 2 do CNPq. 